\title{
Business intelligence and the role of external information in small- and medium-sized enterprises of the Finnish marine industry
}

ARTICLE in INTERNATIONAL JOURNAL OF INNOVATION AND REGIONAL DEVELOPMENT · JANUARY 2013

DOI: 10.1504/IJIRD.2013.059859

READS

17

2 AUTHORS, INCLUDING:

Teemu Makkonen

University of Surrey

21 PUBLICATIONS 17 CITATIONS

SEE PROFILE 


\title{
Business intelligence and the role of external information in small- and medium-sized enterprises of the Finnish marine industry
}

\author{
Teemu Makkonen ${ }^{12 *}$, Antti Saurama \\ ${ }^{1}$ Pan-European Institute, Turku School of Economics at the University of Turku, Rehtorinpellonkatu 3, FI-20500 \\ Turku, Finland, teemu.makkonen@utu.fi \\ ${ }^{2}$ Department of Geosciences and Geography, University of Helsinki, Finland \\ ${ }^{3}$ Centre for Collaborative Research, Turku School of Economics at the University of Turku, Rehtorinpellonkatu \\ 3, FI-20500 Turku, Finland, antti.saurama@utu.fi \\ * Corresponding author
}

\section{Biographical notes}

Teemu Makkonen holds a PhD in Economic Geography (University of Helsinki, 2012). He is currently working as a Postdoctoral Researcher in the Pan-European Institute, Turku School of Economics at the University of Turku. He has published several articles on innovation and regional knowledge-based development.

Antti Saurama is currently working as a Development Manager in the Centre for Collaborative Research, Turku School of Economics at the University of Turku. He was formerly the Head of Unit of Research and Consulting Services at the Centre for Maritime Studies, University of Turku. He has acquired extensive experience and knowledge of the marine industry through numerous research projects with which he has been involved.

This is an Accepted Manuscript of an article published by Inderscience in International Journal of Innovation and Regional Development on March 18, 2014, Vol. 5, No. 3, pp. 266278. Available online: http://dx.doi.org/10.1504/IJIRD.2013.059859 


\begin{abstract}
The availability of external data sources and information for firms has expanded in recent decades. At the same time, the importance of business intelligence (BI) in the competition between firms has been increasingly highlighted. This competition poses challenges, however, especially for small- and medium-sized enterprises (SMEs). The purpose of this paper is to delineate a general picture of the conditions of the role of external information in BI as it applies to SMEs in the Finnish marine industry. According to the results, the use of external information in BI was generally occasional and unsystematic. This was due to time and resource limitations to be allocated for BI. However, the interest in developing BI processes is evident. Thus, this study puts forward development proposals that promise to help SMEs enhance and rationalise their BI processes, according to the development targets that they have identified.
\end{abstract}

\title{
Keywords
}

Business intelligence, Finland, Innovation, Marine industry, Regional development, SME

\section{Introduction}

The literature refers to business intelligence (BI) in a simplified way as a systematic process whereby firms gather, analyse and utilise information in their decision-making processes and to business intelligence systems (BIS) as an integrated set of tools, technologies and program products utilised to collect, integrate, analyse and disseminate data (Hannula and Pirttimäki, 2003; Popovič et al., 2012; Wixom and Watson, 2012). Information and data sources can be internal (information concerning the firm's performance) or external (Pirttimäki, 2004). However, firms are generally reluctant to share with outside investigators their intelligence practices related to internal information (Wright and Calof, 2006). Therefore, the main emphasis in this paper will be on the role of external information, which normally includes competitor, market, technology, product, customer and partner information. 
The potential to use external information in BI for firms has grown in recent decades for several reasons, including technical development and the increase in the sheer amount of data available. It follows, then, that many firms struggle to manage this excess of information. In general, the challenge for many firms has, thus, shifted from finding to screening out only the necessary, but especially managing this information. At the same time, the importance of information and the search for external knowledge in the competition between firms in the modern innovation-driven economy has become increasingly vital (Knoben and Oerlemans, 2010; Skalkos and Bakouros, 2011), as enterprises seek competiveness and competitive advantage through BI. This imposes considerable challenges, especially for small- and medium-sized enterprises (SMEs), where the resources for systematic BI, large technical applications, human resources allocated to BI and the acquisition of information services are more limited than for large-scale enterprises.

The current financial crises and problems faced by many European shipyards have added to this discussion (Ionescu, 2011). In Finland in particular, many traditional marine industry (especially shipbuilding) regions are facing problems as orders for new ships have decreased or ceased altogether. Bearing in mind the whole supply chain of an individual ship from start (planning) to finish (shipyards), this is extremely problematic as different sectors within the industry work in different stages. Thus, when orders cease, the firms engaged in the planning side face immediate problems, layoffs, etc. This, of course, has a negative impact on the regional development of marine industry intensive localities. Thus, the ability of firms to predict or forecast rather than merely react to changes in their business environment is crucial. BI offers one means to accomplish this (Bose, 2008) 
The purpose of this paper is to draw a general picture of the conditions of BI and the role of external information in the SMEs of the Finnish shipbuilding industry, to identify the most essential needs and challenges and to propose actions to support individual firms and the development of that sector. The specific focus on SMEs is not only policy relevant (Small Business Act of the Commission of the European Communities, 2008), but typifies the structure of the industry, since over $80 \%$ of firms in the shipbuilding industry in the EU-27 countries are SMEs (ECORYS, 2009). The sample and results of this paper are based on a survey conducted by the Centre for Maritime Studies, University of Turku (Makkonen et al., 2008).

The remainder is organised as follows. First, a short introduction describes the conceptual backgrounds of BI and presents relevant empirical BI literature. Second, the paper presents the study design (i.e., the sample and methods) and its limitations. Third, a depiction of the most relevant results is provided followed by a discussion and conclusions of the most important development targets identified by the firms, as well as suggested proposals for helping SMEs in their BI processes.

\section{Conceptual backgrounds of business intelligence and relevant empirical literature}

BI is both a process (a set of methods) and a product (intelligence that will help firms to predict developments in their business environment) (Jourdan et al., 2008). Although, there is no generally agreed definition of BI, there is a set of different ways to specify the concept. This study uses the definition by Hannula and Pirttimäki (2003): 'The BI concept is described as organized and systematic processes which are used to acquire, analyze and disseminate information significant to firms' business activities'. Related concepts (hereafter referred broadly as BI), including competitive (often used as a synonym for BI), competitor, corporate, 
customer, market, strategic and technical intelligence, are also commonly used to describe similar processes (du Toit, 2003; Porter, 1980; Viviers et al., 2005; Wright and Calof, 2006). However, BI is normally considered an umbrella concept encompassing the other intelligence-related terms (Lönnqvist and Pirttimäki, 2006). Similarly, knowledge management is sometimes confused with $\mathrm{BI}$ : whereas BI focuses on explicit knowledge, knowledge management encompasses both tacit and explicit knowledge (Cody et al., 2002; Herschel and Jones, 2005; Nonaka \& Takeuchi, 1995).

Based on its definition, BI is, thus, an ongoing and systematic process whereby raw data are transformed into useful knowledge. The phases of a typical BI process appear in Figure 1. For alternative process models see Pirttimäki and Hannula (2003). The first stage defines the need for intelligence, which is of the utmost importance for SMEs to avoid the allocation of resources toward something that is ultimately unnecessary (Vitt et al., 2002). According to the needs, the data or pre-processed information are then gathered from relevant sources and processed in the third stage into a structured form, which can be then analysed in the fourth stage. The analysed information is then disseminated to all relevant personnel through various means (including reports etc.). In the last stage, intelligence is utilised and feedback is given in order to begin the next round in the BI process. Without the last stage, the BI is rather useless for the firm, as only BI processes that actually lead to action can be considered valuable (Thierauf, 2001). This depiction is, of course, a crude generalisation; in real life the relationships between different phases are not so distinct and chronological. Rather, there are several feedback loops between the different stages. Still, the figure does provide us with an overall picture of BI the process. 
The lack of BI can be considered a major deficiency in the operations of firms: ineffectiveness in decision-making may lead to financial losses. Furthermore, whereas in the early days BI was viewed and used exclusively to support tactical and operational decision-making, organisations have recently began to exploit BI to support wider business activities such as the supply chain, production and customer services (Elbashir et al., 2008). In particular, effective BI can serve as a tool to support and improve the innovation processes of firms (Lemos and Porto, 1998). Concomitantly, several studies have theorised that the use of BI correlates with good business performance (Cavalcanti, 2005; Davcev and Kulakov, 2012; Davenport and Harris, 2007; Thomas, 2001). However, it is difficult for firms to recognise concrete returns from BI (Pirttimäki et al., 2006; Popovič et al., 2010).

Commonly used BIS include data, text and web mining, data warehousing and visualizationbased tools (Chau et al., 2007; Chung et al., 2005; Popovič et al., 2012; Wang and Wang, 2008;). External information for BI is usually acquired from competitors, customers and the business environment via interviews, news reports, patent data and the Internet ( $\mathrm{Li}$ et al., 2007; Shih et al., 2010; Tekic et al., 2012). Thus, the information gathering does not involve illegal activity (e.g. industrial espionage, etc.), as the data are gathered from public information sources (Crane, 2005; Lemos and Porto, 1998). This is especially relevant to the marine industry, as it constitutes a network of companies (often working together in different stages of ship building). Therefore, the idea of collaboration in BI is appealing to the marine industry (Rizzi, 2012). At the same time, however, firms have implemented counterintelligence techniques to minimise the outflow of information about their activities (West, 1999). 
Empirically the condition of BI has been studied mainly vis-à-vis large enterprises. Previous studies of the BI processes of large companies (Bose, 2008; Calof and Wright, 2008; Halonen and Hannula, 2007; Koskinen et al., 2005; Pirttimäki and Hannula, 2002) have revealed that larges companies have organised the use of BI in a systematic way and that they are ready to invest more to develop their BI processes. Still, BI is usually integrated into parts of other business activities. However, Halonen and Hannula (2007) have shown that firms that have a responsible employee or a separate unit for BI with an allocated budget perform and develop BI in more efficient ways, because of the more structured approach, than do those that do not. One possibility for enhancing the efficiency of BI is to outsource it (Salonen and Pirttimäki, 2005). However, part of BI will always be kept within a company because it cannot be outsourced. This deals with informal information obtained through direct contacts between clients and suppliers. The outsourced parts are the more standardised monitoring of indicators, publications or other open information. Thus, most large firms have already outsourced some parts of their BI processes (Hirvensalo, 2004). Similarly, enterprises expect the co-operation and networking in BI to increase in future, as these activities and the benefits derived from them are currently under-utilised (Hannula and Pirttimäki, 2003). Still, the fostering of networking between firms should be fastened to inherent partnerships, not to the false notion that every firm is eager to collaborate: the lack of this understanding has proved to be a major hurdle for BI co-operation (Bergeron, 2000).

Previous studies have shown that employees, as a source for valuable information on the external business environment, are an important asset (Vuori, 2006). At the same time, this emphasises the importance of other personnel in BI, as vast potential is lost if $\mathrm{BI}$ is used only by managers (Mäkipää, 2004; Saayman et al., 2008). As BI increasingly becomes a part of the personnel's work and decision-making in the contemporary knowledge economy, the need for 
proper BI training for personnel is considered important. Continuous training is, thus, one of the most important facilitators for BI, as are other tools for securing competitive advantage, such as innovations (Eckerson, 2004; Makkonen and Lin, 2012). Accordingly, employees' low skill levels and the shortage of available training services have been considered as major shortcomings for fully utilising BI (de Pelsmacker et al., 2005; du Toit, 2003; Viviers et al., 2005).

Evidently more is known about large organizations, but the degree to which such knowledge applies to SMEs is not: as noted by Bergeron (2000) there is a need to better understand the information needs and uses by SMEs. As an exception within the BI literature that mostly concerns large companies, Lampela (2005) has studied the BI processes of SMEs, and concludes that a lack of resources in BI imposes greater limitations on SMEs than on large enterprises. Wright et al. (2002) have drawn similar conclusions on SMEs, though at the same time emphasising that this need not to be the case. Thus, BIS of SMEs should be organised as lightly as possible and require cheap and lightweight architectures and tools (Grabova et al., 2010). Moreover, in the case of SMEs the significance of data storing in a logical manner and the need for industry-specific databanks for SMEs were deemed extremely important. However, the creation of an industry-specific databank requires an independent organisation to co-ordinate the content of the databank (Lampela 2005).

\section{Sample, methods and limitations}

The data were gathered through a net-based survey designed for SMEs (according to available information on the size and annual turnover of the firms) in the Finnish marine industry. To ensure face validity, the questionnaire was constructed by taking into account numerous previous surveys (Halonen and Hannula, 2007; Koskinen et al., 2005; Lampela, 2005; 
Pirttimäki and Hannula, 2002) as well as the views of the representatives of the Finnish Maritime Cluster Programme. To facilitate responding, the questionnaire was in Finnish and it included a short introduction to the definitions of BI and external information. The questionnaire was sent to 220 firms representing SMEs in the Finnish marine industry. A total of 46 chief executive officers (CEO) of SMEs, supplemented with nine interviews, participated: the data cover the views of 55 CEOs of SMEs (the response rate was 25\%). Basic information about the sample appears in Table 1. Most of the companies worked exclusively or mainly in the marine industry (74\% of the respondents), most often for Finnish shipyards. For a more detailed description of the sample, see Makkonen et al. (2008). Bearing in mind the sample size, the methods employed in this paper are descriptive: we used basic distribution and cross-tabulation statistics.

$<$ Table 1 about here>

The most obvious limitation of this study concerns the relatively small sample size. However, we consider our sample to be representative of the SMEs throughout the Finnish marine industry (Karvonen and Holma, 2009). Thus, the generalisations based on our sample are justified when treated with requisite caution, as is often true of studies based on a sample. Another limitation of this study is its confinement to one country. However, the firm-size composition of most European shipbuilding countries resembles that of Finland in that they are dominated by SMEs (ECORYS, 2009).

\section{Results}

Our results suggest that the use of external information in BI was largely occasional (Figure 2). Still, $16 \%$ of the responding firms claimed to have systematic processes for the use of 
external information in BI. Moreover, one third of the firms that use external information occasionally, were planning to develop their processes towards the systematic use of external information, but more than half of the responding firms were planning to expand their investment in the acquisition and utilisation of external information in future. The single most important target for development was information gathering (identified by $69 \%$ of the respondents), followed by the utilisation of employee information and development of the dissemination of information (both identified by $40 \%$ of the respondents). The firms that had systematic processes for the use of external information in BI were generally larger than those that did not. Moreover, firms that used no external information in BI at all did business solely with domestic customers. The greatest limitation on the use of external information in BI was the shortage of time allocated for these processes (identified by $56 \%$ of the respondents). Also, many firms (49\% of the respondents) feel that, because of their established and thin clientele (most companies were supplying only domestic shipyards, which indeed are few), they had no need to scan for external information. However, as noted by Thomas (2001), this is insufficient reason to ignore the importance of external information. In fact, the need for external information most often coincided precisely with a change in the customer base of the firm (identified by $49 \%$ of the respondents) and on other occasions, when new competition arose (identified by $43 \%$ of the respondents) or enterprises sought collaboration and networking partners (identified by $34 \%$ of the respondents). Most of the firms considered the condition of their BI in relation to external information to be either good or at least fair (Figure 2). Firms that had systematically organised their BI in relation to external information were more satisfied with their processes than were firms that did not.

$<$ Figure 2 about here> 
Executives were most often in charge of BI in the responding firms and they also utilised external information most regularly (the case in $63 \%$ of the respondents' firms). Altogether, BI collectively employed only about $20 \%$ of a person-year in the average company. External information was most often used in planning and development as well as in marketing. Consequently, the most important sectors of external information were seen to be competitor, customer and market intelligence. The most important sources for external information for the respondents were news reports (utilised by $80 \%$ of the respondents), seminars or conferences (utilised by $77 \%$ of the respondents) and the firm's own personnel (utilised by $61 \%$ of the respondents). Usually, the information was stored and disseminated in an ad hoc manner (i.e. only occasionally and unsystematically). Moreover, there were no real rules for disseminating information that would have guaranteed its successful application. Only a few firms (two respondents) had a separate person in charge, dedicated software (seven respondents) or an allocated budget for BI (four respondents): BI and screening for external information most often occurred alongside other work duties. Similarly, only a few companies had outsourced their external information gathering processes (four respondents), although some were planning to do so in the near future (seven respondents). The perceived pros and cons of BI were those regularly stated in the BI literature (Halonen and Hannula, 2007; Lampela, 2005). The pros included the sharpened forecasting of threats (identified by $72 \%$ of the respondents) and market possibilities (identified by $74 \%$ of the respondents) as well as the increase in the overall intelligence of the business environment (identified by $74 \%$ of the respondents). Again, the lack of available resources (identified by $64 \%$ of the respondents) and the difficulties in identifying any concrete returns from BI (identified by $26 \%$ of the respondents) were the most common cons reported by the firms. 


\section{Discussion and conclusions}

The use of external information in BI in SMEs of the Finnish marine industry seems to be rather occasional. This came as no surprise, since many of the responding firms were quite small, which is also true for the marine industry as a whole. However, bearing in mind the advantage of $\mathrm{BI}$, there are promising signs that the use of external information in $\mathrm{BI}$ is becoming more and more organised and systematic. Furthermore, previous studies (Davenport and Harris, 2007) have shown that, in addition to increased satisfaction with the perceived state of BI, the gains from it will grow as processes are developed in a more systematic direction. According to the responding firms, there are many targets for development regarding the use of external information in particular, and BI in general: they are listed in Table 2 from the most commonly identified toward less frequently (but still often) identified. Development proposals that could help firms in their BI processes appear also in Table 2. The development proposals are drawn from the results of this survey and from previous literature presented in the literature review. As BI is a continuous process, the development proposals overlap: some of the proposals can serve to improve the process in several stages (cf. Figure 1). The goal is to develop the use of external information in BI in individual firms as well as in the marine industry as a whole.

$<$ Table 2 about here>

The proposals put forward here should be treated according to firm size: for micro firms, the framework for BI and BIS should be lighter than for medium-sized enterprises:

- Exploiting existing analyses and information services (e.g. with data mining processes) would help firms to rationalise their information acquisition and cut costs in the process: many organisations constantly produce valuable information about the 
sector in the form of surveys, reports and databases that firms should take advantage of.

- Appointing an employee in charge of information acquisition (the position need not be a full-time occupation, but a part-time task) would save 'hidden costs', time and money, as only one person would follow the information sources and disseminate useful parts of it to the rest, unlike in a situation where most of the personnel are screening or verifying the same data unaware of the other.

- Information should be disseminated in an organised and systematic manner: it is important that all employees know and understand the rules governing available information, as well as when and to whom it should be disseminated, otherwise firms risk the possibility that valuable information will be lost, if it remains underutilised.

- Documenting the `silent` knowledge possessed by the employees would significantly increase the opportunities to utilise the information that already exists within the organization by documenting an exhibition, conference or seminar excursion by company employees in such a way that the information can be disseminated to other personnel (however, this requires the information to be tailored and targeted; otherwise it only creates an information overflow).

- Increasing the valued added from external information could be achieved by training personnel that should be organised in a light, flexible and ongoing manner in order to keep the personnel 'up-to-date'.

- As some of the acquired external information can become outdated relatively fast, the amount of stored information should be limited such that it does not require constant updating, whereas in other cases, the main focus should be on disseminating the information that should be acquired ad hoc. 
- In specific cases, outsourcing could help firms to identify their intelligence needs in information acquisition.

- Increased networking, when mutual needs arise, could solve some of the problems faced by SMEs: joint-acquisition of services would lower firm-specific costs and enhance the potential for smaller firms to follow external information about their business environment (however, the feasibility of networking is somewhat hampered by mistrust among firms and the possibility of data falsification).

- One possible solution could be an industry-specific databank maintained by an industry-specific `non-profit’ organisation.

Although the case here focuses on Finnish SMEs in the marine industry it potentially reflects the situation in other Scandinavian as well as European countries. Thus, the results and recommendations have wider relevance. A firm requires a competitive advantage to survive, and BI offers a means to achieve this. Therefore, other SMEs, irrespective of their industry classification, could benefit from benchmarking their BI processes to the experiences gained from the SMEs in the Finnish marine industry (Huggins, 2010). Thus, the recommendations offered here are not only case-specific for Finland, but can be applied to other European counterparts in order to compete in the important arenas of $\mathrm{BI}$, innovation and regional development.

\section{Acknowledgements}

This work is part of Academy of Finland project no. 127213. The Machine Technology Center Turku Ltd. provided their financial support for this study and is identified as the sponsor of the survey entitled Ulkoisen liiketoimintatiedon hallinta ja kehittämistarpeet suomalaisissa pienissä ja keskisuurissa meriteollisuusalan yrityksissä, on which the results of this paper are based on. This paper is a revised and expanded version of a paper entitled External business intelligence in small- and medium-sized enterprises - A case study of the 
Finnish marine industry presented at the 5th International Conference for Entrepreneurship, Innovation and Regional Development held in Sofia, Bulgaria on 1-2 June 2012. The authors thank Mr Arttu Paarlahti for help with the figures, Dr Gareth Rice his for help with the language editing, and the reviewers for their helpful comments in improving the paper.

\section{References}

Bergeron, P. (2000) 'Regional business intelligence: the view from Canada', Journal of Information Science, Vol. 26, No. 3, pp.153-160.

Bose, R. (2008) 'Competitive intelligence process and tools for intelligence analysis', Industrial Management \& Data Systems, Vol. 108, No. 4, pp.510-528.

Calof, J. and Wright, S. (2008) 'Competitive intelligence: a practitioner, academic and inter-disciplinary perspective', European Journal of Marketing, Vol. 23, No. 7, pp.717-730.

Cavalcanti, E.P. (2005) 'The relationship between business intelligence and business success', Journal of Competitive Intelligence and Management, Vol. 3, No. 1, pp.6-15.

Chau, M., Shiu, B., Chan, I. and Chen, H. (2007) 'Redips: backlink search and analysis on the web for business intelligence analysis', Journal of the American Society for Information Science and Technology, Vol. 58, No. 3, pp.351-365.

Chung, W., Chen, H. and Nunamaker, J.F. (2005) 'A visual framework for knowledge discovery on the web: an empirical study of business intelligence exploration', Journal of Management Information Systems, Vol. 21, No. 4, pp.57-84.

Cody, W.F., Keulen, J.T., Krishna, V. and Spangler, W.S. (2002) 'The integration of business intelligence and knowledge management', IBM Systems Journal, Vol. 41, No. 4, pp.697-713.

Commission of the European Communities (2008) 'Think small first: a "Small Business Act" for Europe', available at: http://ec.europa.eu/enterprise/policies/sme/small-business-act/ (accessed on 6 June 2012).

Crane, A. (2005) 'In the company of spies: when competitive intelligence gathering becomes industrial espionage', Business Horizons, Vol. 48, No. 3, pp.233-240.

Davcev, L. and Kulakov, A. (2012) 'The impact of the information technology on the business sector development', in Birov, D. and Todorova Y. (Eds.): Proceedings of the $5^{\text {th }}$ International Conference for Entrepreneurship, Innovation and Regional Development, Sofia University, Sofia, pp.191-196. 
Davenport, T.H. and Harris, J.G. (2007) Competing on Analytics: The New Science of Winning, Harvard Business School Press, Boston.

de Pelsmacker, P., Muller, M-L., Viviers, W., Saayman, A., Cuyvers, L. and Jegers, M. (2005) 'Competitive intelligence practices of South African and Belgian exporters', Marketing Intelligence \& Planning, Vol. 23, No. 6, pp.606-620.

du Toit, A.S.A. (2003) 'Competitive intelligence in the knowledge economy: what is in it for South African manufacturing enterprises', International Journal of Information Management, Vol. 23, No. 2, pp.111-120.

Eckerson, W. (2004) 'The best BI tool is education', Business Intelligence Journal, Vol. 9, No. 2, pp.4-5.

ECORYS (2009) Study on the Competitiveness of European Shipbuilding Industry, ECORYS, Rotterdam.

Elbashir, M.Z., Collier, P.A. and Davern, M.J. (2008) 'Measuring the effects of business intelligence systems: the relationship between business process and organizational performance', International Journal of Accounting Information Systems, Vol. 9, No. 3, pp.235-253.

Grabova, O., Damont, J., Chauchat, J-H. and Zolotaryova, I. (2010) 'Business intelligence for small and middlesized enterprises', SIGMOD Record, Vol. 39, No. 2, pp.39-50.

Halonen, P. and Hannula, M. (2007) 'Liiketoimintatiedon hallinta suomalaisissa suuryrityksissä 2007', eBRC Research Reports, No. 37. (in Finnish)

Hannula, M. and Pirttimäki, V. (2003) 'Business intelligence: empirical study on the top 50 Finnish companies', Journal of American Academy of Business, Vol. 2, No. 2, pp.593-599.

Herschel, R.T. and Jones, N.E. (2005) 'Knowledge management and business intelligence: the importance of integration', Journal of Knowledge Management, Vol. 9, No. 4, pp.45-55.

Hirvensalo, I. (2004) 'Competitive intelligence in Finland', Journal of Competitive Intelligence and Management, Vol. 2, No. 2, pp.22-37.

Huggins, R. (2010) 'Regional competitive intelligence: benchmarking and policy-making', Regional Studies, Vol. 44, No. 5, pp.639-658.

Ionescu, R. (2011) 'Competition on the global shipbuilding market under the global crisis impact', Acta Universitatis Danubius Economica, Vol. 7, No. 5, pp.5-15.

Jourdan, Z., Rainer, R.K. and Marshall, T. (2008) 'Business intelligence: an analysis of the literature', Information Systems Management, Vol. 25, No. 2, pp.121-131.

Karvonen, T. and Holma, E. (2009) 'Lounais-Suomen meriklusteri 2009', Turun yliopiston Merenkulkualan koulutus- ja tutkimuskeskuksen julkaisuja B, No. 171. (in Finnish) 
Knoben, J. and Oerlemans, L. (2010) 'The importance of external knowledge sources for the newness of innovations of South African firms', International Journal of Innovation and Regional Development, Vol. 2, No. 3, pp.165-181

Koskinen, A., Pirttimäki, V. and Hannula, M. (2007) 'Liiketoimintatiedon hallinta suomalaisissa suuryrityksissä 2002-2005', eBRC Research Reports, No. 21. (in Finnish)

Lampela, H. (2005) Liiketoimintatiedon hallinta ja jalostaminen pk-yrityksissä, Lappeenrannan teknillinen yliopisto, Lappeenranta. (in Finnish)

Lemos, Â.D. and Porto, A.C. (1998) 'Technological forecasting techniques and competitive intelligence: tools for improving the innovation process', Industrial Management \& Data Systems, Vol. 98, No. 7, pp.330-337.

Li, F.L., Cheung, C.F., Lee, W.B. and Kwok, S.K. (2007) 'Business intelligence for new market development: a web semantic network analysis approach', International Journal of Enterprise and Network Management, Vol. 1, No. 3, pp.261-282.

Lönnqvist, A. and Pirttimäki, V. (2006) 'The measurement of business intelligence', Information System Management, Vol. 23, No. 1, pp.32-40.

Mäkipää, M. (2004) 'Liiketoimintatiedon hallinnan rooli ja muodot strategisessa johtamisessa', Tampereen yliopiston Tietojenkäsittelytieteiden laitoksen raportteja D, Vol. 2004, No. 4, pp.103-115. (in Finnish)

Makkonen, T. and Lin, B. (2012) 'Continuing vocational training and innovation in Europe', International Journal of Innovation and Learning, Vol. 11, No. 4, pp.325-338.

Makkonen, T., Saurama, A. and Sundberg, P. (2008) 'Ulkoisen liiketoimintatiedon hallinta ja kehittämistarpeet suomalaisissa pienissä ja keskisuurissa meriteollisuusalan yrityksissä’, Turun yliopiston Merenkulkualan koulutus- ja tutkimuskeskuksen julkaisuja B, No. 160. (in Finnish)

Nonaka, I. and Takeuchi, H. (1995) The Knowledge-Creating Company, Oxford University Press, New York.

Pirttimäki, V. (2004) 'The roles of internal and external information in business intelligence', Frontiers of $e$ Business Research, Vol. 2004, No. 1, pp.385-396.

Pirttimäki, V. and Hannula, M. (2002) 'Business intelligence suomalaisissa suuryrityksissä 2002', $e B R C$ Research Reports, No. 4. (in Finnish)

Pirttimäki, V. and Hannula, M. (2003). 'Process models of business intelligence', Frontiers of e-Business Research, Vol. 2003, No. 1, pp.250-260.

Pirttimäki, V., Lönnqvist, A. and Karjaluoto, A. (2006) 'Measurement of business intelligence in a Finnish telecommunications company', The Electronic Journal of Knowledge Management, Vol. 4, No. 1, pp.83-90. 
Popovič, A., Turk, T. and Jaklič, J. (2010) 'Conceptual model of business value of business intelligence systems', Management, Vol. 15, No. 1, pp.5-30.

Popovič, A., Hackney, R., Coelho, P.S. and \& Jakliè, J. (2012) 'Towards business intelligence systems success: Effects of maturity and culture on analytical decision making', Decision Support Systems, Vol. 54, No. 1, pp. 729-739.

Porter, M. (1980) Competitive Strategy: Techniques of Analyzing Industries and Competitors, Free Press, New York.

Rizzi, S. (2012) 'Collaborative business intelligence', in Aufaure, M.A. and Zimanyi, E. (Eds.), eBISS 2011, Springer-Verlag, Heidelberg, pp.186-205.

Saayman, A., Pienaar, J., de Pelsmacker, P., Viviers, W., Vuyvers, L., Muller, M-L. and Jegers, M. (2008) 'Competitve intelligence: construct exploration, validation and equivalence', Aslib Proceedings, Vol. 60, No. 4, pp.383-411.

Salonen, J. and Pirttimäki, V. (2005) 'Outsourcing a business intelligence function', Frontiers of e-Business Research, Vol. 2005, No. 1, pp.661-675.

Shih, M-J., Liu, D-R. and Hsu, M-L. (2010) 'Discovering competitive intelligence by mining changes in patent data', Expert Systems with Applications, Vol. 37, No. 4, pp.2882-2890.

Skalkos, D. and Bakouros, I. (2011) 'Innovation management technique (IMT) for very small-enterprises: concept, development and application', International Journal of Innovation and Regional Development, Vol. 3, No. 6, pp.573-603.

Tekic, Z., Kukolj, D., Nikolic, L., Pokric, M., Drazic, M. and Vitas M. (2012) 'SMEs, patent data and new tool for business intelligence', in Birov, D. and Todorova Y. (Eds.): Proceedings of the $5^{\text {th }}$ International Conference for Entrepreneurship, Innovation and Regional Development, Sofia University, Sofia, pp.855863.

Thierauf, R.J. (2001) Effective Business Intelligence Systems, Quorum Books, Westport.

Thomas, J.H. (2001) 'Business intelligence - why?’, eAI Journal, Vol. 2001, No. July, pp.47-49.

Wang, H. and Wang, S. (2008) 'A knowledge management approach to data mining process for business intelligence', Industrial Management \& Data Systems, Vol. 108, No. 5, pp.622-634.

West, C. (1999) 'Competitive intelligence in Europe', Business Information Review, Vol. 16, No. 3, pp.143-150.

Vitt, E., Luckevich, M. and Misner, S. (2002) Business Intelligence: Making Better Decisions Faster, Microsoft Press, Redmond. 
Viviers, W., Saayman, A. and Muller, M-L. (2005) 'Enhancing a competitive intelligence culture in South Africa', International Journal of Social Economics, Vol. 32. No. 7, pp.576-589.

Wixom, B. and Watson, H. (2012) 'The BI-based organization', in Herschel, R.T. (Ed.): Organizational Applications of Business Intelligence Management: Emerging Trends, IGI Global, Hershey, pp.193-208.

Wright, S. and Calof, J. (2006) 'The quest for competitive, business and marketing intelligence: a country comparison of current practices', European Journal of Marketing, Vol. 40, No. 5, pp.453-465.

Wright, S., Pickton, D. and Callow, J. (2002) 'Competitive intelligence in UK firms: a typology', Marketing Intelligence \& Planning, Vol. 20, No. 6, pp.349-360.

Vuori, V. (2006). 'The employees as a source of external business intelligence information', eBRC Research Reports, No. 31, pp.81-96.

\section{Tables and figures}

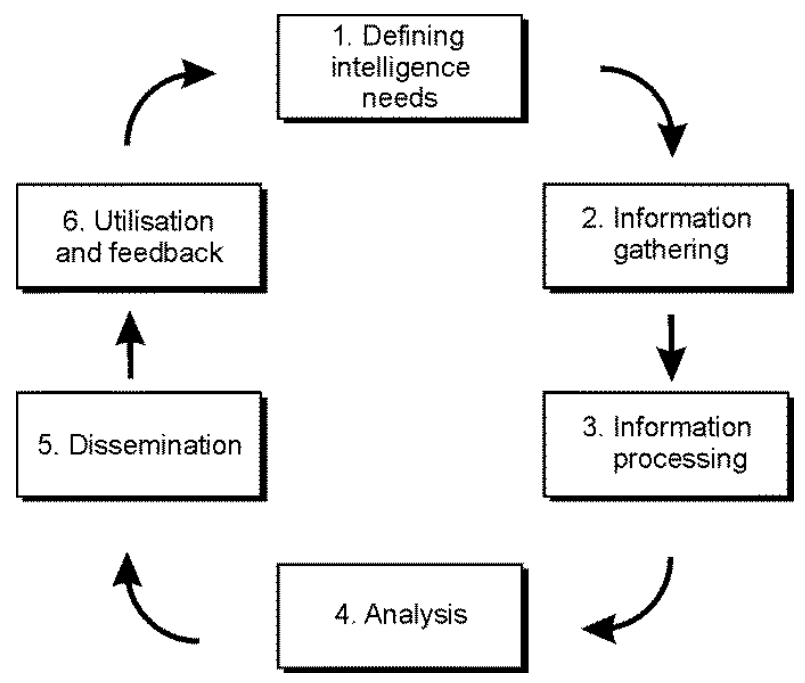

Figure 1. The main steps of a typical BI process (adapted from Salonen and Pirttimäki, 2005).

Table 1. Background characteristics of the sample.

\begin{tabular}{|c|c|c|c|}
\hline & Micro (< 10 employees) & Small (10-50 employees) & Medium (> 50 employees) \\
\hline \multirow[t]{2}{*}{ Size group } & $11 \%$ & $43 \%$ & $46 \%$ \\
\hline & $<5$ mill. $€$ & 5-20 mill. $€$ & $>20$ mill. $€$ \\
\hline \multirow[t]{2}{*}{ Annual turnover } & $48 \%$ & $35 \%$ & $17 \%$ \\
\hline & Manufacturing & Assembly & Planning and other services \\
\hline $\begin{array}{l}\text { Main activity in } \\
\text { the marine sector }\end{array}$ & $60 \%$ & $16 \%$ & $24 \%$ \\
\hline
\end{tabular}



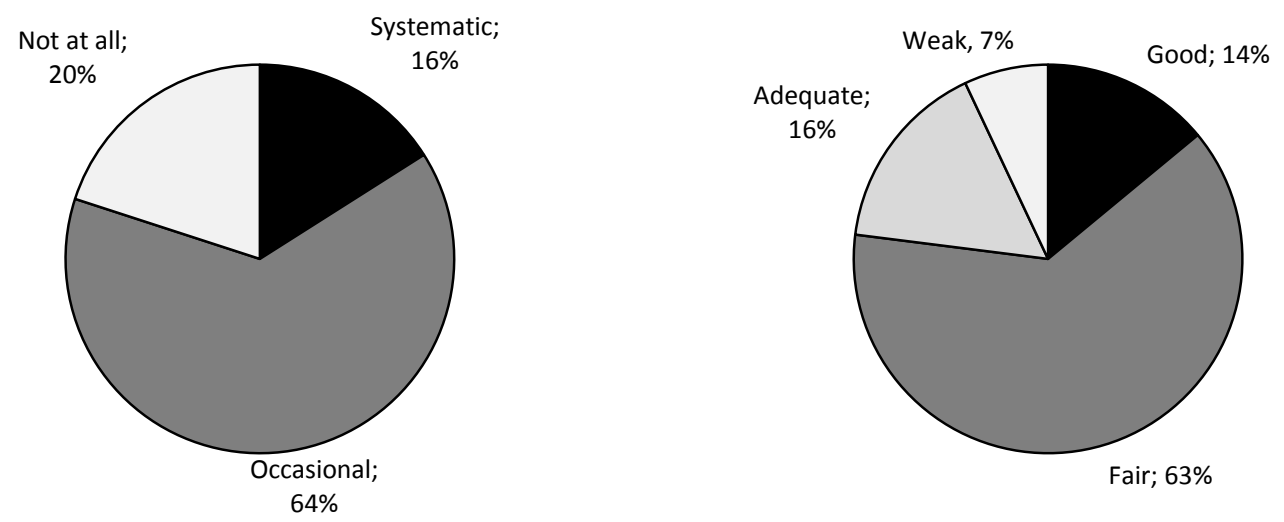

Figure 2. The rate of use of external information in BI among responding firms (left) and their own estimation of the state of BI in relation to external information in their firms (right).

Table 2. The most essential development targets and proposals of BI.

\section{Development targets}

Rationalising information acquisition

(a)

Utilising employee information

Increasing added valued

Rationalising documentation

Identifying intelligence needs

Increasing networking

\section{Development proposals}

Exploiting existing analyses and information services

Clarifying practices

Documenting `silent' knowledge

Training personnel

Developing documentation

Outsourcing

Developing an industry specific databank 